\title{
Gender and class in Miura Atsushi's karyū shakai [low-stream society]: Literature review
}

\author{
ANNETTE SCHAD-SEIFERT
}

\section{Introduction}

Post-war Japan until the 1990s has often been characterized as a "classless" society, with only minor differences between rich and poor. However, since the late 1990s the issue of the dissolution of Japan's mass middle class has featured both in the media and academic debates and numerous authors - such as Kariya Takehiko (2001), Sato Toshiki (2000, 2002), Tachibanaki Toshiaki $(1998,2004,2005)$, Yamada Masahiro $(2004,2006)$ and Shirahase Sawako $(2005,2006)$ - have dealt with the growing social divide in Japanese society and the trend toward greater economic inequality.

One of the researchers who have contributed most actively to the discourse on Japan as a society of growing social gaps is sociologist and market analyst Miura Atsushi, who is also the founder and chairman of the Culture Studies Institute for Market Research. In 2004, one year after family sociologist Yamada Masahiro coined the word kakusa shakai [society of widening gaps], Miura began publishing a conspicuous bulk of literature on this growing social divide (Miura 2005a, 2005b, 2006a, 2006b, 2007a, 2007b; Miura and Ueno 2007). In these books Miura describes the changing attitudes, lifestyles and consumption patterns of, in particular, young people by applying the term karyū shakai [literally: "low-stream society"], indicating that Japanese society is losing its "midstream" $($ ch $\bar{u} r y \bar{u})$ character and is instead becoming more and more divided. The newly coined Japanese term kary $\bar{u}$ had scarcely been used in public before Miura gave it a new meaning in his publications, whereas chüryu is a term of wide currency. English translations usually refer to chüryu as "middle class," although it in fact only means "social middle" or, perhaps more accurately, "mainstream," as anthropologist William W. Kelly (2002: 234) has interpreted it. 
Japan's social scientists have often stated that the majority of Japanese people identify themselves as chüryū (Roberts 2005: 104), a self-classification that goes back, for example, to Murakami Yasusuke who in the 1970s focused his research on the emergence in Japan of a "new middle class stratum" (atarashii chūkan kaisōo) (Murakami 1978, 1982). Since then Murakami has founded his social analyses on annual surveys conducted by the Cabinet Office that have measured the population in terms of their standard of living, consumption patterns and material well-being. Murakami found out that a growing part of the population - in the 1980 s up to 90 per cent - placed themselves in the social middle class and that, during the period of high economic growth during the bubble, the living standards of people with working class backgrounds rose to middle-class levels, a development that helped to shape today's "mid-stream consciousness" (chüryzu ishiki) among the Japanese population in general (Roberts 2005: 108).

Although these findings contributed to the popular media discourse on Japan's "90 percent middle class" society, it should be noted that the "social middle" is not congruent with the "middle class" in sociological class analysis, since chüryū connotes social status in terms of a level of material well-being, standard of living as well as consumption patterns and, what is more, includes people of different occupational and educational backgrounds. Therefore Japanese social scientists held a fierce debate over whether analytical determinants of social position can be measured objectively and whether the emerging "social middle" class could be identified as one great middle class (Murakami et al. 1980).

Since 1955, a group of Japanese sociologists has conducted a survey every ten years in which Japan's social stratification and social mobility is measured (i.e., the Social Stratification and Social Mobility Survey, abbreviated as SSM in the following). Since then, five studies have been evaluated. The surveys applied determinants such as professional employment (shokugyo kyaria), educational background (gakureki), and social status (shakaiteki chii), as well as status-defined determinants such as occupational and educational attainment of the parents (usually the father). A closer look at the SSM surveys shows that the concept of middle class was applied with various implications. Obviously the subjective factor played an important role in the apparently objective stratification assessment. The SSM surveys covered three different definitions of middle class: First, 'economic middle class' (chūsan kaikyū), secondly, 'mid-stream status' (chūryū kaikyū) and thirdly 'middle stratum' (chükan kaisō). The category of 'economic middle class' still has the closest reference to the Marxist theory of class, as it is related to 'capitalist class' (shihonka kaikyū) and 'working class' (rōdōsha kaikyū). Japanese sociologist Odaka Kunio (1996: 446) has assumed that the category of 'eco- 
nomic middle class' bears associations with financial assets and income, whereas the classification 'mid-stream status' refers to a person's relative status in social relationships and is derived from the family status, educational background and the recognition and prestige that a person receives from its social environment. In other words, a white collar office worker with a university degree, whose income is far below that of a small entrepreneur or a skilled blue collar worker, would have identified himself with mid-stream status because of his educational background.

All surveys showed that the percentage of people who regarded them-

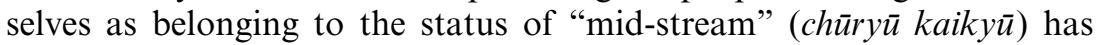
always been higher than the percentage of people who identified as being economic "middle class" (chūsan kaikyū), a result that reveals a high status inconsistency of Japanese society (Odaka 1996: 446). The significant difference here lies in the fact that "middle class" is identified by occupation, whereas "mid-stream" is not.

In 1999, the two sociologists Hara Junsuke and Seiyama Kazuo undertook a comprehensive review of the SSM studies and presented a renewed analysis of Japanese society (Hara and Seiyama 1999, 2005; Hara 2007). They concluded that class identification and class consciousness were influenced clearly by the desire to become materially "affluent," but that nonetheless Japan has always been a socially and economically divided society in which polarization is not a recent phenomenon. Despite this assessment, Kelly's discussion (2002: 237) of the term chüryū as "mainstream" remains relevant here. He states that the hegemonic force and standardizing character of "mid-stream" identification has been a unifying factor in Japan's post-war society in the face of existing social differences and cultural exclusions. The following will use the insight of this critique on the "mid-stream" as a popular term of Japanese self-identification to discuss the discourse on karyu and the ways in how this term has been presented by Miura as challenging the "mid-stream" ideological forces of Japanese society.

\section{The definition of "low-stream society"}

Miura's analysis of karyu is not a study of the "lower classes" in a conventional understanding of class. Miura's analysis neither dwells on poverty issues nor homeless people nor a type of social existence that Karl Marx would have called the "rag proletariat" (Lumpenproletariat). Instead Miura deals with the question of what happens to a society in which the majority of people are moving down the social ladder towards the lower-middle and bottom strata of society. In his analysis he is not so much concerned with resource distribution and the allocation of incomes, but rather with lifestyles at the cultural level, as well as the levels 
of status identity and consumption, referring with the term karyu to the "lower-middle class" or the "lower middle" (naka no shita). Members of this stratum are described generally as being neither economically poor, nor lacking any essential everyday commodities; rather they represent attitudes and values that differ from those of both their parents' generation and the post-war generation. Miura himself identifies their weak motivation (iyoku) for upward status attainment as the most characteristic feature of this group, since they are showing "low communication skills, little experience in life, casual inclination towards work and education, and low consumption needs" (Miura 2005a: 7). In contrast to the all "mid-stream" society, which was characterized by conspicuous consumption and a desire for social advancement, Miura maintains that the values of the "lower-middle class" show a tendency towards social withdrawal and a slow pace of life, and that, in particular, members of the second baby boom generation are beginning to descend into this stratum (Miura 2005a: 88).

While the majority of Japanese citizens have identified themselves positively with being mid-stream, one would not expect that descending to "low-stream" or even having a lower-class inclination would be desirable. The social effects of a shrinking middle class are usually regarded as posing a threat to social harmony and, therefore, taking up the issue of lower-middle-class lifestyles is a project that challenges the traditional view of class analysis, which in fact hardly ever deals with downward mobility or with a society that is losing its meritocratic forces (Delphy and Leonard 1986: 69).

Significantly, Miura's first of a two volume publication on low-stream society, entitled Karyū shakai: Aratana kaisō shüdan no shutsugen [Lowstream society: The emergence of a new class formation] (Miura 2005a), deals with different attitudes towards the lower, upper middle, and upper class, sold 800.000 copies and became a bestseller, particularly among readers of the younger generation receptive to his findings. While academics such as economist Tachibanaki $(1998,2004,2005)$ and sociologist Satō $(2000,2002)$ have constantly cautioned against the dissolution of the middle class by describing the detrimental effects of growing income and opportunity disparities, Miura's publications follow a different approach in trying to come to terms with the reality of a society that has already altered its structure into "low-stream" (Miura 2005a). What has called the attention of readers to Miura's best-selling books is probably his detailed accounts of new social trends and consumer patterns which are explicitly not middle-class any more.

Miura's publications form part of the popular media discourse, but it should be noted that he is presenting his comments from the point of view of a marketer or market analyst who focuses strongly on new life- 
styles and recent types of consumer behaviour, as for instance in his surveys conducted for the department store PARCO. Miura recommends that manufacturers and fashion designers in Japan should respond to these new market trends that emerged with the growth of the lower middle classes. In the past, he claims, markets could rely on the stable mass purchasing power of the all mid-stream society, whereas the recent diversification of consumption patterns into a small upper middle and a mass lower middle is yet to be fully explored from a marketing viewpoint.

Miura's treatment of gender aspects too attracted media attention. All the differentiation that Miura deals with in terms of social class and status he also categorizes in terms of differences between men and women. In his second book on the low-stream society, entitled Kary $\bar{u}$ shakai dai ni shō: Naze otoko wa onna ni "maketa" no ka [Low-stream society, part two: Why were men "outplayed" by women?] (Miura 2007a), he surveys consumption patterns, employment status and emerging family models with regard to people's expectations and hopes for the future. As indicated by the subtitle, this book presents a rather provocative treatment of the topic because, behind this winners-versus-losersrhetoric, Miura observes that young women seem to be better prepared to deal with precarious living conditions than young men.

\section{Classes and gender groups in the discourse on low-stream society}

Miura bases his data on surveys and opinion polls conducted by the Japanese government, newspaper publishers such as Asahi Shimbun and Yomiuri Shimbun, as well as his own Culture Studies Institute. By providing his own statistics he not only aims at complementing the picture of Japanese social trends, but also tries to challenge conventional views on the growing social divide. For Miura the low-stream society is a social formation characterized by a variety of new types of consumption, which are fragmented not only into various patterns of participation in consumption, but also reveal divergence between women and men, as well as growing differences both among women and among men.

Miura categorizes five types of young female consumers, each belonging to a different class status. Among them two types can be identified as still representing the old middle class: firstly the so-called "bride type" (o-yome kei) - that is, young marriage-oriented women from an upper middle class family background; and secondly the "average OL type" ( futsū no OL kei) - young office assistants or "office ladies", who spend their small incomes almost entirely on individual leisure consumption while still living in their parents' household. A symbol of the growing re-differentiation of Japanese society is a third type, the "millionaise type" (mirionēze kei), represented by young high-income females, who 
earn an average annual income of ten million yen. The lower strata of society are represented by the "girl type" (gyaru kei) - a category that comprises female members of teenage subcultures who dress themselves in flashy and sexually provocative clothes - and (5) "Kamayatsu woman" (Kamayatsu onna kei) who acquired this name from their sloppy outfits and predilection for wearing old hats that copy a fashion style created by the Japanese country musician Kamayatsu Hiroshi. For Miura the lifestyles and values of the "girl type" and the "Kamayatsu women" are particularly in stark contrast to those of the established middle classes (Miura 2005a: 43-68).

These five female types correspond to only four different types of male consumers. These are: (1) the "young executive type" (yangu eguzekutibu $\mathrm{kei}$ ), represented by young well-educated men with jobs in high-ranking international companies in the financial and IT sectors. Similar to the female "bride types", these young executives symbolize the privileged strata of the established middle classes. Another group which Miura has labelled as a new phenomenon in the Japanese consumer market is (2) the socalled "LOHAS type" (LOHAS kei). LOHAS, which stands for "Lifestyles of Health and Sustainability," are represented by a growing group of consumers in industrialized countries, who tend to shop for naturally grown, high-quality and whole food products. Their spending power clearly classifies them as upper and medium middle class. The remaining two groups both show a tendency towards downward social mobility and thus correspond to the lower strata in the classification of female types, namely (3) the "SPA! type" (SPA! kei) consisting of male readers of the Japanese weekly SPA! magazine, and (4) the so-called "freeter type" ( furîta $\mathrm{kei}$ ) comprising young males working in part-time jobs.

For Miura members of the "SPA! type" display rather weak commitment to their work. The name itself is derived from SPA! magazine, an entertainment magazine with a conservative touch, which finds its readers mainly among middle- and low-income male office workers (sarariman). Since their jobs are not particularly well compensated, members of the "SPA! type" have only a little design brand orientation and instead usually wear generic clothes (UNIQLO or Suits Company). For Miura, their taste is typical of the lower-middle classes and resembles that of the otaku generation. The "freeter type" on the other hand has a strong tendency towards self-actualization, but they live an economically impoverished life with an average annual income of two million yen (Miura 2005a: 72-87).

\section{The changing status of men in the low-stream society}

Before publishing his study of the low-stream society, Miura was interested predominantly in female consumers and their social status in terms 
of purchasing power. However, in his second book (Miura 2007a) he has become particularly focused on the situation of young men and their changing social identity. For Miura the social status of low income men in non-regular employment correlates with difficulties in finding a marriage partner, since the economic qualification for men to marry is still regarded in terms of having the financial means to support a family as the sole breadwinner (husband/father).

In the first chapter of his second book Miura (2007a: 15-23) describes young men "who want to lean on someone" (sugaritai otokotachi), explaining that while in the past middle-class men have never expected their wives to earn a considerable income, lower-class males now require an income from their potential marriage partner that is roughly equivalent to their own or even higher (Miura 2007a: 27). In the group of lowincome men below the age of 35, almost 50 per cent are looking for a partner with a higher income than their own. Miura is convinced that lower-class young men are becoming increasingly less biased towards the traditional breadwinner model and instead are prepared to let themselves become economically dependent on their wives - that is, if they are able to find a marriage partner at all. For Miura the main reason for this change in values is that men, who in previous generations were "corporate soldiers", have increasingly lost the opportunity of relying on their companies and therefore are trying to find economically strong women as partners (Miura 2007a: 31-32). This frankly expressed male dependency wish is probably the main reason why Miura sees young men of low income as being "losers" against women.

\section{Downward mobility in a changing labour market}

The increase in the number of persons of the freeter type - that is, young people who are working in non-regular employment or who voluntarily quit their jobs - is seen by many social scientists as the main reason why Japan has turned into a divided society (Genda 2005, 2007; Tachibanaki 2004; Kosugi 2008; Yamada 2004). Until the 1990s, in the majority of cases, working part time (pāto taimu) was a status designated only to married and middle-aged women who, due to their low income and social security status, were dependent mainly on the income of their husbands. Part-time jobs carried out by high school or university students on the other hand are called arubaito; and both male and female graduates, who - in terms of their credentials - would be able to work as regular company employees, but instead take up non-regular employment - for whatever reason - are labelled furī arubaita (more commonly abridged as furīta $)$. However, women are labelled furīta only while they remain unmarried. All in all, the status distinction and income dis- 
parities between regular workers (seishain) and these non-regular workers (hiseiki shain) are particularly high in Japan and constitute a trend toward downward mobility, which is particularly striking among freeters.

In the third chapter of his second book on the low-stream society Miura analyses the reasons why men in particular decide not to become regular employees. From March to April 2006, he conducted a nationwide survey of 10,000 participants consisting of 20 to 44-year-old males, categorized by age and occupational status including (a) regular employees, (b) self-employed/freelance workers, (c) temporary employees, (d) employees of the furitta type, (e) the jobless, and (f) those categorized as NEET - Not in Employment Education or Training. The result showed that, with regard to class consciousness (kaiso ishiki), 16.3 per cent of respondents placed themselves in the upper stratum, 38.9 per cent in the middle stratum and 44.8 per cent in the lower stratum of society (Miura 2007a: 21) and that, in the lower stratum, almost 50 per cent of respondents belonged to the age group 25 to 34 .

As another point of reference Miura quotes results from the "General surveys on diversified types of employment" (Shügyō keitai no tayōka ni kansuru sōgō jittai chōsa) (Kōsei Rōdōshō 2003), conducted by the Japanese Ministry of Labour in 2003. Featuring interviews asking non-regular employees about their desired work style for the future (kongo no kibō suru hatarakikata), a significant result of the questionnaire, in Miura's view, is that only 19.4 per cent of all non-regular employees aspired to become permanent workers. Another survey by the same ministry conducted in 2006 revealed that the majority $(85 \%)$ of male students in their twenties working part-time and 52 per cent of female students working part-time are expecting to become regular employees within the next ten years (Kōsei Rōdōsho 2006). Miura concludes from these findings that young people, when graduating from high school or university, have high expectations of becoming regular employees sometime in the future, but that those who have already taken up non-regular employment as furîta $\bar{a}$ do not feel inclined to become regular workers for the time being (Miura 2007a: 74). Obviously, the reason for this is that regular jobs impose many constraints on young employees. Therefore, Miura maintains, if the social status of part-time workers could be improved, many would prefer to remain furit $\bar{a}$, and if the conditions imposed on full-time workers were relaxed, many would try to become regular company employees.

Although most companies are convinced that high salaries and the chance of promotion are the merits of the salaryman status, young people fear that a higher salary also means more demands placed on them in terms of overtime and burdensome transfers. Therefore, Miura criticizes interpretations which assume that the majority of young people in Japan 
in any case aspire to regular employment status, as for example the one that Tachibanaki (2004) provided in his book on furīta society. According to Tachibanaki, more than 80 per cent of male non-regular workers and more than 50 per cent of female non-regular workers are seeking regular employment. Miura supposes that Tachibanaki's interpretation was simply not correct, because respondents were actually asked what kind of professional status they had aspired to immediately after graduating from high school or university, arguing that the results would be different, if people in current part-time employment were interviewed. According to a survey conducted in 2006 by Asahi Shimbun, only about 50 per cent of male persons and 20 per cent of female persons in nonregular jobs would rather wish to change to regular employment, whereas more than 50 per cent of female persons would prefer to receive higher salaries as part-timers than consider pursuing full-time employment (Miura 2007a: 70). Miura supposes that non-regular or part-time work as such is not seen as problematic as long as conditions of payment and social security are improved.

In Miura's view the Japanese clothing company UNIQLO has already understood the change in consciousness among Japanese young adults and started advertising full-time contracts on a regular status but without any transfers at all - so-called chiiki gentei seishain [literally: "locally bound regular employee"] positions with salaries that are lower than those of transferable workers (Miura 2007a: 76). Miura's own Culture Studies Institute revealed in a 2006 "Survey on work and life of men, first questionnaire" (Dansei shigoto - Seikatsu chōsa, daiichiji chōsa) that the level of satisfaction with life among young men employed in casual work as furit $\bar{a}$ is high and that they are still quite optimistic about their future while young (CSI 2006, quoted from Miura 2007a). A total of 52 per cent of interviewees in the 25 to 29 age group responded that they had a chance of becoming employed on a regular basis in the next five years, and that only furit $\bar{a}$ in the 35 to 39 age group said that they had given up hope of reaching full-time employment and expected to remain as part-timers in the long term. It is highly probable that those who do not find a full-time positions before the age of 35 will stay in part-time positions for the rest of their lives, unless they start their own business - a trend that Miura describes as having become more common in recent years (Miura 2007a: 77-79).

Furthermore, Miura's data shows that the correlation between nonregular employment and lower class inclination is strong among all age groups except among the youngest cohort in his sample, namely those aged 20 to 24. It is surprising that, in this age cohort, the NEETs are not only the best off in terms of their satisfaction with life, but also that their self-assessed social status is high when compared to jobless persons, 
furīta , temporary workers, and even self-employed persons, and only slightly below the level of regular workers.

By type of household, the percentage of persons still living with their parents is 54.1 per cent for regular employees, 64.7 per cent for temporary workers, 64.4 per cent for furitt $\bar{a}$, and 56.6 per cent for NEETs (Miura 2007a: 84). It should be noted, however, that in the 20 to 24 age group the "still living with their parents" household type is not the largest among young male NEETs, as might be expected; instead, the "unmarried and single" household type shows the highest rate $(39.1 \%)$, compared to regular employees $(34.9 \%)$, temporary workers $(30.9 \%)$, and furit $\bar{a}(30.0 \%)$. However, the annual income of NEETs is by far the lowest (56.8\% have "no income at all," while $38.9 \%$ receive an annual income of "less than 1 million yen") compared to the incomes of regular employees (39.2\% in the "between 3 and 5 million yen" category) and those of temporary workers ( $41.2 \%$ "between 1.5 and 3 million yen" and $16.2 \%$ "between 3 and 5 million yen"). Moreover, even jobless NEETs have opportunities to earn a small income by trading on Internet auctions for example, which allows them to at least sustain themselves in otaku-like manner, as Miura (2007a: 86-87) puts it.

Miura's main points are that being part of the social low-stream does not necessarily imply discontent and that being employed as a part-timer does not in any case have to coincide with a lack of hope for the future. Instead, he adds, young males in regular employment often feel more pessimistic about their lives than persons in casual employment (Miura 2007a: 6).

\section{The changing status of women in the low-stream society}

Miura has dealt with the changing social status of women in a variety of publications (Miura 2005b, 2006a), but in his two books on the lowstream society he dwells less on the issue of young women's lives, although he describes the changing female status as being rather complex. In the last chapter of his second book, Miura draws on findings from a "Survey on unmarried women and married women without children" (Mikon, kikon-konashi josei chōsa) conducted by his Culture Studies Institute in 2006. The sample comprised 516 women aged 28 to 32 .

Miura found that young women increasingly appreciate full-time work in contrast to young men's growing contempt for regular employment. He further concludes that status consciousness is particularly high among married women in regular employment, while achieving professional housewife status after getting married is not given high priority any more. Furthermore, female respondents employed in casual work 
expressed high levels of satisfaction with having the opportunity to lead an autonomous lifestyle independent of their parents.

Women today, during the course of their lives, have several different options in terms of occupational, marital and household status. As far as social status is concerned, the highest status identity is attributed to married and regularly employed women, followed by the group of married women in irregular employment and then the group of single women in regular employment. The lowest status is attributed to single women who work part time, 37.9 per cent of whom identify themselves as being low-stream (Miura 2007a: 187), whereas even after marriage the selfperception of women as belonging to the middle-class stratum remains strong even if the respondent's employment status has changed from regular to non-regular (Miura: 2007a: 190). This shows that class attributions for women are strongly influenced by both marital status and household type. Being married or living in a household with affluent parents gives women the consciousness of belonging to the upper-middle or medium-middle class. Therefore, for Miura, married females in regular employment are the social "winners" compared to all other groups of the same sample. In terms of economic well-being, 41.7 per cent of this sample have an annual income of more than 4 million yen, whereas 43.3 per cent of married women in part-time employment have annual incomes below one million yen. For Miura (2007a: 197) this difference is reflected in the savings behaviour of couples, that is, whether the family has enough money to purchase a home or afford a good education for their children. In this regard the employment status of women directly influences the economic gap between married couples.

The pressure to find a marriage partner is particularly high among women working as furitta because marriage offers them the opportunity to quit irregular employment and to enhance their own social status. Miura also found that "being attractive" is a serious concern particularly among female temp workers who tend to copy the dress style of "Ebichan" (Ebihara Yuri), a famous model who "embodies the attractive cuteness of the Japanese pretty woman type" (Miura 2007a: 204).

\section{Conclusion: Does the social formation of lower class bring about new relations of gender and class?}

After the publication of Miura's description of a society that is about to lose its middle-class identity, the Japanese media documented with astonishment that the number of young Japanese adults who positively identify with being lower middle class is growing. Many critics believed that Miura's provocative description of the "low-stream society" would evoke harsh protest; but, instead, a group of interviewees who were fea- 
tured in AERA magazine assented with Miura's analysis (Hamada 19 December 2005: 20-21). AERA journalist Hamada Nami suggested as an explanation for this change of mind that, in the past, remaining at a lower social status had caused embarrassment, but that today since the number of people dropping out of the middle class is increasing, a positive image of "low-stream" is developing as well - a development, it should be noted, to which Miura's discourse has significantly contributed.

The question remains, however, as to whether the changes in the status of young people in Japan is being adequately analysed in the discourse on the low-stream society. It is important to understand how and why processes of downward social mobility have a different impact on men and women as individuals. Arguably, the growing number of male parttimers can be interpreted as a sign of the feminization of work places, something that will radically change men's status, individual life chances and expectations for the future. But for young men the ongoing changes of employment structures have led, at least potentially, to the possibility of leading alternative lifestyles, while young women have increasingly better chances of combining professional careers and family. Nevertheless, any rhetoric that postulates men and women as coherent groups pitted against each other as "winners" and "losers" is unproductive when trying to understand processes of structural change.

Miura explains that the search for self-fulfillment and individuality is obviously a strong motivation when young men opt for furit $\bar{a}$ employment, although this choice might not be ideal in terms of a secure livelihood. A question that Miura leaves unanswered is why still many more young women than young men find their way into temporary jobs. Certainly, among the younger age groups, the percentage of non-regular employees is extremely high for both sexes, particularly among those aged 15-19 (male 66.5\%, female 78.63\%) and those aged 20-24 (male $36.55 \%$, female $44.60 \%$ ). But the female percentage is always higher than the male one, and in the 25-29 age group the male percentage falls to 12.91 per cent compared to a female rate of 36.59 per cent (Ishiguro 22 December 2008: 4).

The middle-class family with the male breadwinner-housewife couple has been the standard, from which gender relations have evolved in postwar Japanese society. From the perspective of those who defend this gender order, the dissolution of the middle class evokes at least three scenarios of national threats, namely decreasing household consumption, less economic productivity, and a shrinking of the national population. Therefore, most of the discourses on the growing re-differentiation of society have described this trend as a crisis that will disrupt social cohesion (e.g., Yamada 2004, 2006). Indeed, many approaches seem to 
be particularly concerned about younger males who are defined as social drop-outs with a tendency to remain single, live in celibacy and socially isolate themselves as otaku. Interpretations that take the dissolution of the middle class as an opportunity to deal with new and diversified forms of lifestyles and values are scarce. A more constructive approach is given in a study by political activist Matsumoto Hajime and sociologist Suzuki Kensuke in their (2008) publication Sayōnara karyū shakai [Farewell to the low-stream society], in which they introduce work styles and occupational careers of young people living beyond the company employee and furit $\bar{a}$ path. Matsumoto and Suzuki put forward the idea that the trend towards downward mobility has been induced by the scarcity of occupational options in Japanese society, and therefore they promote an active search for what they define as "living creatively" (kurieitibu ni ikiru) (Matsumoto and Suzuki 2008: 15). This lifestyle is exemplified by young people who have become organic farmers or artists or have moved back to the countryside - a lifestyle that consists of constantly giving meaning to one's own life according to one's individual abilities.

The fact that women are described as appearing to be less affected by economic risks and possessing better skills to deal with poor prospects for the future also has to be questioned. The reason behind this view is that the middle-class gender prescription for women defines them as non-holders of class status, who reach their social position only vicariously by means of marriage, family membership and household communality. Miura ignores the fact that household communality and intergenerational social security transfers have become important issues in male biographies as well. NEETs who live alone on almost no income obviously receive considerable financial support from their parents, a fact that again proves that the growing number of people with low status achievement among the young generation is profoundly induced by an affluent parents' household supporting them. Miura leaves the question as to why NEETs place themselves in the upper level of class status entirely open, but it can be assumed that the family background plays a role in this, since only parents who are affluent enough can afford to feed an adult family member for a longer period of time. And evidence for this is presented by sociologist Genda Yūji (2007), who has empirically examined this group in more detail.

Sociologists such as Shirahase $(2005,2006)$, on the other hand, stress that an individual's economic poverty and low level of livelihood security can remain "invisible" for a long period and that today women are still more vulnerable of falling into poverty at a higher age than men. Her research presents approaches showing how class status can be analysed with respect to differences in age, gender, and household communality. 
Any analytical perspective that tries to intersect class and gender specific structures has to consider how belonging to a class is based on individual biographical strategies that take place both in occupational fields as well as in households and families. This holds true for both men and women. What is problematic in Miura's analysis is that he considers male and female strategies in terms of an individual risk game. But the "winner versus loser" rhetoric maintained by Miura fails to acknowledge that women and men do not constitute self-contained status groups any more; his own analysis reveals - somehow contradictorily - that gender groups have actually become fragmented and diverse. In co-authorship with sociologist Ueno Chizuko, Miura has sustained his view that lifestyles in the low-stream society are getting more complex, and that disparities are not only reorganized between the sexes but also growing among women and among men (Miura and Ueno 2007). Nevertheless it is clear that Miura wished to achieve precisely this provocative rhetoric in order to draw the reader's attention to the importance of the social divide and how it influences people's new lifestyles, attitudes, and consumption patterns. Given that discourses form and construct meaning and the ways in which people conceive themselves as social subjects, Miura's books have challenged traditional views on social stratification effectively.

Annette Schad-Seifert (schad@phil-fak.uni-duesseldorf.de) is professor of Modern Japanese Studies at Heinrich Heine University Düsseldorf. Her main fields of research are contemporary cultural and social discourse, as well as gender studies of Japan.

\section{References}

Asahi Shinbunsha. 2006. Kaiso ishiki no seron chosa [Public opinion poll on class consciousness]. Tokyo: Asahi Shinbunsha.

CSI (Cultural Studies Institute). 2006. Dansei shigoto - Seikatsu chosa, daiichiji chosa [Survey on work and life of men, first questionnaire]. In Atsushi Miura (2007a), Karya shakai dai-ni-sho: Naze otoko wa onna ni "maketa" no ka [Low-stream society, part two: Why are men "outplayed" by women?]. Tokyo: Kobunsha.

Delphy, Christine \& Diana Leonard. 1986. Class analysis, gender analysis and the family. In Rosemary Crompton \& Michael Mann (eds.), Gender and stratification, 57-73. Cambridge: Polity Press.

Genda, Yuji. 2005. A nagging sense of job insecurity: The new reality facing Japanese youth. Jean Connell Hoff (trans.). Tokyo: International House of Japan.

Genda, Yuji. 2007. Jobless youths and the NEET problem in Japan. Social Science Japan Journal 10 (1). 23-40.

Hamada, Nami. 2005. Happi karyajin no yuga na seikatsu [The comfortable life of the happy low-stream people]. AERA Asahi Shimbun Weekly. 20-21, 19 December.

Hara, Junsuke. 2007. Contemporary Japanese society and the new inequalities: A frontier of social stratification and inequality research. In Yoshimichi Sato (ed.), 
Deciphering stratification and inequality: Japan and beyond, 3-17. Melbourne: Trans Pacific Press.

Hara, Junsuke \& Kazuo Seiyama. 1999. Shakai kaisō: Yutakasa no naka no fubyōdō [Social stratification: Inequality amid affluence]. Tokyo: Tōkyō Daigaku Shuppankai.

Hara, Junsuke \& Kazuo Seiyama. 2005. Inequality amid affluence. Social stratification in Japan. Brad Williams (trans.). Melbourne: Trans Pacific Press.

Ishiguro, Kuniko. 2008. Japanese employment in transformation: The growing number of non-regular workers. Electronic journal of contemporary Japanese studies. 22 December. http://www.japanesestudies.org.uk/articles/2008/Ishiguro.html (accessed 9 November 2009).

Kariya, Takehiko. 2001. Kaisōka Nihon to kyōiku kiki - Fubyōdō saiseisan kara iyoku kakusa shakai (insentibu dibaido) $e$ [Japan's trend toward stratification and the education crisis - From reproduction of inequality to social disparity (incentive divide)]. Tokyo: Yūshindō Kōbunsha.

Kelly, William W. 2002. At the limits of new middle-class Japan: Beyond "mainstream consciousness". In Oliver Zunz, Leonard Schoppa \& Nobuhiro Hiwatari (eds.), Social contracts under stress. The middle classes of America, Europe and Japan at the turn of the century, 232-254. New York: The Russel Sage Foundation.

Kōsei Rōdōshō (Ministry of Health Labor and Welfare). 2003. Shngyō keitai no tayōka ni kansuru sōgō jittai chōsa hōkoku: Heisei 15-nen [General survey on diversified types of employment]. Henshūsha Kōsei Rōdōshō Daijin Kanbō Tōkei Jōhōbu Koyō Tōkeika.

Kosugi, Reiko. 2008. Escape from work: Freelancing youth and the challenge to corporate Japan. Melbourne: Trans Pacific Press.

Matsumoto, Hajime \& Kensuke Suzuki (eds.). 2008. Sayōnara karyū shakai [Farewell to the low-stream society]. Tokyo: Popurasha.

Miura Atsushi. 2005a. Karya shakai: Aratana kaiso shadan no shutsugen [Low-stream society: The emergence of a new class formation]. Tokyo: Kobunsha.

Miura Atsushi. 2005b. "Kamayatsu onna" no jidai: Josei kakusa shakai no torai [The age of the "Kamayatsu woman": The emergence of a society of social gaps between women]. Tokyo: Makino Shuppan.

Miura, Atsushi. 2006a. Jōryū na watakushi? Karyū na watakushi? [Am I upper class or am I lower class?] Tokyo: PHP Kenkyūjo.

Miura, Atsushi. 2006b. Maihōmuresu chairudo: Karyū shakai no wakamonotachi [Children without a home of their own: Young people in a low-stream society]. Tokyo: Bungei Shunja.

Miura, Atsushi. 2007a. Karyū shakai dai-ni-shō: Naze otoko wa onna ni "maketa" no $k a$ [Low-stream society, part two: Why are men "outplayed" by women?]. Tokyo: Kōbunsha.

Miura, Atsushi. 2007b. Kakusa ga iden suru: Kodomo no karyūka o fusegu ni wa [Social gaps are hereditary: In order to prevent children from becoming low-stream]. Tokyo: Takarajimasha.

Miura, Atsushi \& Chizuko Ueno. 2007. Shōhi shakai kara kakusa shakai e: Chūryū dankai to karyū junia no mirai [From consumer society to a society of social gaps: The future of mid-stream baby boomers and low-stream juniors]. Tokyo: Kawade Shobō Shinsha.

Murakami, Yasusuke. 1978. The reality of the new middle class. The Japan Interpreter. A Journal of Social and Political Ideas 12 (1). 1-5.

Murakami, Yasusuke. 1982. The age of new middle mass politics: The case of Japan. Journal of Japanese Studies 8 (1). 29-72.

Murakami, Yasusuke, Shigenobu Kishimoto \& Ken'ichi Tominaga. 1980. The reality of the new middle class. Tokyo: Foreign Press Center. 


\section{2}

Odaka Kunio. 1996. The middle classes in Japan. In Reinhard Bendix \& Seymour Martin Lipset (eds.), Class, status, and power: Social stratification in comparative perspective, $2^{\text {nd }}$ edn., 541-551. Glencoe, IL: Free Press.

Roberts, Glenda S. 2005. Shifting contours of class and status. In Jennifer Robertson (ed.), A companion to the anthropology of Japan, 104-124. Oxford: Blackwell.

Sato, Toshiki. 2000. Fubyodo shakai Nihon - Sayonara socharya [Japan's unequal society: A farewell to the mass middle class]. Tokyo: Chūō Kōron Shinsha.

Sato, Toshiki. 2002. Zero zero nendai no kakusa gemu [The disparity game of the generation born 2000 and later]. Tokyo: Chno Koronsha.

Shirahase, Sawako. 2005. Shoshikoreishakai no mienai kakusa: Jenda, sedai, kaiso no yukue [Invisible inequalities in an ageing society with low fertility rates: The impact of gender, generation and class]. Tokyo: Tokyo Daigaku Shuppankai.

Shirahase, Sawako. 2006. Fubyodoka Nihon no nakami [The content of Japan's trend towards unequality]. In Sawako Shirahase (ed.), Henka suru shakai no fubyodoShoshikoreika ni hisomu kakusa [Inequality in a changing society - Hidden disparities behind the demographic shift in Japan], 47-78. Tokyo: Tokyo Daigaku Shuppankai.

Tachibanaki Toshiaki. 1998. Nihon no keizai kakusa: Shotoku to shisan kara kangaeru [Japan's economic disparities: From the perspective of income and assets]. Tokyo: Iwanami Shoten.

Tachibanaki, Toshiaki. 2004. Datsu furtta shakai - Otonatachi ni dekiru koto [Leaving the society of freeters: How to become an adult]. Tokyo: Tōyō Keizai Shinbunsha.

Tachibanaki, Toshiaki. 2005. Confronting income inequality in Japan - A comparative analysis of causes, consequences, and reform. Cambrigde MA: MIT Press.

Yamada, Masahiro. 2004. Kibo kakusa shakai - "Makegumi" no zetsubokan ga Nihon $o$ hikisaku [Society of expectation gaps - The despair of the "losers" is tearing up Japan]. Tokyo: Chikuma Shobo.

Yamada, Masahiro. 2006. Shinbyodo shakai: "Kibo kakusa” o koete [A new egalitarian society: Overcoming the "expectation gaps"]. Tokyo: Bungei Shunjn. 